\title{
Nekateri vidiki raziskovanja zgodnjega učenja in poučevanja
}

\author{
Tina Štemberger \\ Univerza na Primorskem \\ tina.stemberger@pef.upr.si
}

\begin{abstract}
Področje pedagoške metodologije, ki se ukvarja z raziskovanjem vzgoje in izobraževanja, je zaradi specifike področja, ki ga obravnava, zelo široko in raznoliko. $V$ tem kontekstu se zato znotraj pedagoške metodologije pojavljajo tudi podpodročja, ki se osredotočajo na posamezna področja znotraj vzgoje in izobraževanja. Eno takih je področje raziskovanja otroštva, zgodnjega učenja in poučevanja, ki se v zadnjih desetletjih, zlasti pod vplivom anglosaksonske tradicije, nekoliko odmika od tradicionalne pozitivistične raziskovalne paradigme. $V$ prispevku se zato usmerjamo na specifike raziskovanja zgodnjega učenja in poučevanja, pri čemer posebej izpostavljamo vprašanje etičnosti ter naslavljamo različne pristope in načine zbiranja podatkov pri raziskovanju tega obdobja.
\end{abstract}

Ključne besede: pedagoško raziskovanje, zgodnje učenje in poučevanje, etika, tehnike zbiranja podatkov

\section{Uvod}

Pogledi na zgodnje otroštvo ter s tem na zgodnje učenje in poučevanje so se $\checkmark$ zadnjih desetletjih občutno spremenili, kar je narekovalo tudi potrebo po intenzivnejšem raziskovanju tega področja. Objavljene študije so temeljile na različnih metodoloških okvirih, nastale so tudi pod vplivom različnih družbenih, ekonomskih in političnih potreb. Raziskovanje zgodnjega otroštva se je razvijalo v različne smeri, pojavljale so se nove paradigme, v zadnjem času pa je posebno aktualno vprašanje raziskovanja s participacijo otrok (Langston idr. 2004; Rayna in Leavers 2011; Rutar 2014). V pričujočem prispevku se v kontekstu pedagoškega raziskovanja usmerjamo v etičnost pri raziskovanju zgodnjega otroštva ter $v$ nekatere vidike in posebnosti raziskovanja zgodnjega otroštva ter prikazujemo možne pristope $\mathrm{k}$ raziskovanju in tehniki zbiranja podatkov. Pri tem posebej izpostavljamo dejstvo, da so možni različni raziskovalni pristopi in tehnike zbiranja podatkov ter njihove kombinacije, o čemer se raziskovalec odloča na podlagi ciljev, ki jih v raziskavi zasleduje.

\section{Vprašanje etičnosti}

V raziskovanju se vse bolj poudarja etični vidik, v otroštvu pa je to vprašanje, zaradi starosti in ranljivosti (občutljivosti) otrok, še toliko bolj izpostavljeno 
(Mukherji in Albon 2010). Tudi H. L. Cameron (2015) poudarja, da se pri raziskavah, ki vključujejo otroke, vprašanje etičnosti pojavlja v vseh vidikih raziskovanja.

Med prvimi dilemami se poraja vprašanje kompetentnosti otrok za sodelovanje v raziskavi. A. Langston idr. (2004) izpostavljajo, da je med raziskovalci dolgo prevladovalo mnenje, da se $z$ otroki, mlajšimi od 3 let, ne more kaj veliko raziskovati. To gre po njihovem pripisati predvsem dejstvu, da se je kot znanstveno raziskovanje pojmovalo raziskovanje, ki je potekalo $v$ laboratorijih, medtem ko se je $v$ raziskovanje $v$ avtentičnih okoljih usmerjalo le nekaj raziskovalcev. $V$ povezavi z vprašanjem kompetentnosti otrok za sodelovanje $v$ raziskavi ter $\mathrm{s}$ samim sodelovanjem $v$ raziskavi je potrebno izpostaviti tudi t. i. informirano soglasje (Kodelja 2017), ki je pomemben element raziskav, v katere so vključeni ljudje. Informirano soglasje pomeni, da so se sodelujoči prostovoljno odločili za sodelovanje $v$ raziskavi, da je soglasje posledica svobodne volje in temelji na podlagi informaciji o naravi raziskave, njenemu namenu, uporabi izsledkov, o koristih in tveganjih ter obveznostih udeležencev. Pri tem Kodelja (2017) posebej opozarja na raziskave, v katere so vključeni otroci, ki takšnega soglasja sploh ne morejo dati. Po njegovem prepričanju informirano soglasje predpostavlja avtonomijo in odgovornost, otrok pa, predvsem mlajši, ni avtonomen, ne v moralnem pomenu besede ne formalnopravno odgovoren za svoja dejanja, zato informiranega soglasja za sodelovanje $v$ raziskavi ne more dati. Pri tem se sklicuje tudi na Konvencijo o otrokovih pravicah (1989), ki vsakemu otroku zagotavlja pravico do glasu oz. svobodnega izražanja lastnih mnenj takrat, ko je »sposoben oblikovati lastna mnenja«. Temu nasprotno je mnenje A. Langston idr. (2004), ki trdijo, da tudi zelo majhni otroci lahko izrazijo privolitev ali pa tudi nestrinjanje $z$ vključitvijo $v$ raziskavo. To lahko pokažejo na različne načine, in sicer: (i) ne želijo sodelovati z raziskovalcem; (ii) postanejo nenavadno tiho, (iii) obrnejo se stran in jočejo; (iv) ne želijo uporabljati pripomočkov, ki jih vključuje raziskava. Pri tem je smiselno upoštevati tudi, kot, denimo, izpostavlja koncept stotih jezikov Reggio Emilia, da se lahko otroci (četudi še ne znajo govoriti) izražajo na različne načine, npr. preko glasbe, oblikovanja, risanja, plesa ipd. (RobertsHolmes 2005). Raziskovalec naj bi bil torej občutljiv za otrokova sporočila ter pozoren na spremembe njegovega vedenja, pri čemer so opažanja staršev ali, denimo, vzgojiteljev v vrtcu, ki otroka dobro poznajo, zelo dragocena. Ob tem pa je vendarle potrebno opozoriti še na dvoje (Langston idr. 2004): (i) na možnost, da si otroci želijo ugoditi odraslim in je to razlog, da sledijo aktivnostim oz. sodelujejo v raziskavi, in (ii) na možnost, da otroci sicer sodelujejo, a, kot poudarja Kodelja (2017), ni možno z gotovostjo trditi, da njihovo sode- 
lovanje temelji na razumevanju narave raziskave, njenega namena, uporabe izsledkov, koristi in tveganj ter obveznosti udeležencev.

Formalnopravno so starši (oz. skrbniki) tisti, ki odločajo o vključitvi otroka v raziskavo, vendar pa se postavlja vprašanje, ali morajo pri svoji odločitvi upoštevati tudi otrokovo mnenje. Glede na Konvencijo o otrokovih pravicah (1989) morajo starši ravnati tako, da je odločitev v največjo korist otroka, ter pri tem upoštevati otrokovo starost in zrelost ter vpliv odločitve na otrokovo življenje. Kodelja (2017) zato predlaga, da bi bilo dobro, da bi tudi raziskovalci v prošnji staršem za soglasje zapisali, da naj pri svoji odločitvi upoštevajo tudi mnenje otrok. Ob tem pa H. L. Cameron (2015) opozarja tudi na možnost, da se starši dejansko ne strinjajo s sodelovanjem otrok v raziskavi, a vseeno pristanejo, saj se z moralnega vidika čutijo dolžni zagotoviti otrokovo sodelovanje $v$ raziskavi.

V zadnjem času (Robson 2006) se vse pogosteje pojavlja tudi zahteva po obravnavi in odobritvi raziskovalnega načrta na komisijah za etična vprašanja v raziskovanju, ki naj bi bile oblikovane na univerzah in drugih raziskovalnih institucijah.

\section{Pristopi k raziskovanju}

Z metodološkega vidika sta se na področju raziskovanja vzgoje in izobraževanja, izhajajoč iz različnih filozofskih paradigem, uveljavila dva pristopa (ali dve paradigmi): kvantitativni in kvalitativni. Kvantitativno raziskovanje temelji na pozitivistični in postpozitivistični paradigmi, kvalitativno raziskovanje pa na kritični teoriji in konstruktivizmu (Mažgon 2008). Za kvantitativno metodologijo je značilno, da se usmerja v merjenje, kvantifikacijo, definiranje spremenljivk, oblikovanje in preizkušanje hipotez s statističnimi postopki ter posploševanje rezultatov. Za kvalitativno metodologijo je značilna usmerjenost $v$ raziskovanje in razumevanje posameznikov ali skupin, temelji na prožnih raziskovalnih vprašanjih, podatki se običajno zbirajo preko tesnega sodelovanja $z$ udeleženci raziskave, analiza podatkov temelji na induktivnem sklepanju (Creswell 2014). V nadaljevanju prikazujemo nekatere glavne razlike med raziskovalnima pristopoma (paradigmama).

Mnogi raziskovalci (Aubrey idr. 2000; Mažgon 2008; Marentič Požarnik 1990; Creswell 2008), opozarjajo, da je potrebno narediti premik h kombiniranju pristopov (Creswell 2008) ali k sintezi paradigem pedagoškega raziskovanja (Mužić 1994), torej k uporabi obeh metodologij oz. k paradigmatskemu relativizmu (Mažgon 2008), ki upravičuje uporabo obeh paradigem, ki vodita do odgovorov na raziskovalna vprašanja (Mažgon 2006).

P. Mukherji in D. Albon (2010) ugotavljata, da se na področju raziskovanja 
Preglednica 1 Razlike med kvantitativno in kvalitativno paradigmo

\begin{tabular}{|c|c|c|}
\hline Postavka & Kvantitativna paradigma & Kvalitativna paradigma \\
\hline Cilj & $\begin{array}{l}\text { Pojasnjevanje: napoved in kontrola. } \\
\text { Iskanje vzročno-posledičnih zvez - } \\
\text { kavzalna paradigma. Potrjevanje hi- } \\
\text { potez, ki vodi k trditvam o dejstvih, } \\
\text { splošno veljavnih resnicah. }\end{array}$ & $\begin{array}{l}\text { Kritika, restitucija, emancipacija, re- } \\
\text { konstrukcija. Razumevanje razisko- } \\
\text { vanih pojavov - interpretativna pa- } \\
\text { radigma. Strukturni, zgodovinski } \\
\text { vpogled, posameznikova konstruk- } \\
\text { cija. }\end{array}$ \\
\hline $\begin{array}{l}\text { Metodološki } \\
\text { okvir }\end{array}$ & $\begin{array}{l}\text { Uporaba empirično-analitičnih po- } \\
\text { stopkov, uporaba določenih meto- } \\
\text { doloških instrumentov. }\end{array}$ & $\begin{array}{l}\text { Fenomenološki pristop: hermenev- } \\
\text { tična analiza, intuicija kot vir spozna- } \\
\text { nja. }\end{array}$ \\
\hline $\begin{array}{l}\text { Kriteriji } \\
\text { kakovosti }\end{array}$ & $\begin{array}{l}\text { Rigorozni: notranja in zunanja ve- } \\
\text { ljavnost, zanesljivost in objektivnost. }\end{array}$ & $\begin{array}{l}\text { Verodostojnostni kriterij nepristra- } \\
\text { nosti, ontološka verodostojnost, iz- } \\
\text { obraževalna verodostojnost, kata- } \\
\text { lična verodostojnost (vodi k akciji) in } \\
\text { taktična verodostojnost (omogoča } \\
\text { akcijo), pojavlja se tudi vprašanje o } \\
\text { ustreznosti kriterijev kvalitete. }\end{array}$ \\
\hline $\begin{array}{l}\text { Vloga } \\
\text { raziskovalcev }\end{array}$ & $\begin{array}{l}\text { „Nezainteresirani znanstvenik« kot } \\
\text { informator politike in tistih, ki imajo } \\
\text { moč odločanja. }\end{array}$ & $\begin{array}{l}\text { Odnos zaupanja med raziskovalcem } \\
\text { in raziskovancem, avtentičnost, raz- } \\
\text { iskovalec tudi kot udeleženec razis- } \\
\text { kave (npr. opazovanje z udeležbo.) }\end{array}$ \\
\hline $\begin{array}{l}\text { Učenje za } \\
\text { raziskovanje }\end{array}$ & $\begin{array}{l}\text { Tehnično, kvantitativno, kvalitativno, } \\
\text { vsebinske teorije. }\end{array}$ & $\begin{array}{l}\text { Resocializacija, kvantitativna in kva- } \\
\text { litativna, vrednote altruizma in opol- } \\
\text { nomočenja. }\end{array}$ \\
\hline
\end{tabular}

Opombe Povzeto po Lincoln in Guba $(2000,166)$, Mažgon $(2008,37)$ in Mužić $(1994,14)$.

zgodnjega otroštva povečuje število raziskav, ki so kvalitativne narave, torej temeljijo na interpretativni paradigmi, ki poudarja »naravno okolje«, se pravi raziskovanje v avtentični situaciji. Kot poudarja J. Dunn (2005), je namreč potrebno pri raziskovanju zgodnjega otroštva:

- upoštevati zakonitosti odraščanja in razvoja otrok;

- izvesti raziskavo v situaciji, ki ima za otroka čustven pomen;

- opazovati otroke v vsakdanjih situacijah njihovega vsakdanjega življenja.

\section{Raziskave v okviru zgodnjega učenja in poučevanja}

V nadaljevanju predstavljamo naslednje raziskave, za katere menimo, da bi preko njih lahko uresničevali raziskovalne cilje na področju zgodnjega učenja in poučevanja: pregledna raziskava, etnografska raziskava, študija primera, akcijska raziskava, pristop kritičnega dogodka, mozaični pristop. 


\section{Pregledna raziskava}

Pregledne raziskave so zelo pogost način raziskovanja zgodnjega otroštva. Poznamo t.i. longitudinalne raziskave, ki potekajo dalj časa, ter t.i prečne raziskave, za katere je značilno, da so časovno omejene. Longitudinalne raziskave spremljajo večjo skupino otrok skozi daljše časovno obdobje, npr. od rojstva naprej, in preučujejo vplive različnih okoliščin (npr. razlike v razvoju določenih lastnosti otrok glede na socialno-ekonomski status družin, $v$ katerih odraščajo). Ena takih raziskav je, denimo, raziskava The Millennium Cohort Study, ki je bila izvedena v Združenem kraljestvu in je vključevala 18.800 novorojenčkov, ki so bili rojeni leta 2000 , in je trajala do leta 2007. Rezultati so $v$ splošnem pokazali na velik pomen vpliva okolja in družin otrok na razvoj značilnosti otrok. $V$ prečnih raziskavah pa se podatke od udeležencev zbere le enkrat. Pregledne raziskave praviloma vključujejo veliko število vključenih (ali vzorec) in so usmerjene v posploševanje, ne omogočajo pa natančnega in celostnega vpogleda $v$ zgodnje otroštvo in $v$ obstoječe vzgojno-izobraževalne prakse, pa tudi niso usmerjene $v$ pridobivanje perspektive otrok o obravnavani tematiki (Mukherji in Albon 2010).

\section{Etnografska raziskava}

Za etnografsko raziskavo, ki jo uvrščamo med kvalitativne raziskave, je značilno, da si raziskovalec želi čimbolj »zliti se« s skupino, postati njen član, o tem voditi natančen dnevnik in izvajati opazovanje z udeležbo. Gre za raziskovanje vsakdanjega življenja neke ciljne skupine v njenem okolju (Mukherji in Albon 2010; Štemberger 2017). Pri raziskovanju zgodnjega otroštva je etnografska raziskava pogosto uporabljena za preučevanje otroštva $v$ različnih sociokulturnih kontekstih (James 2007). Take vrste raziskav trajajo dlje časa in so zato tudi uporabne za ugotavljanje in razumevanje otrokovega razvoja skozi čas, smiselne so za identifikacijo ključnih točk v otrokovem razvoju in v okolju (Buchbinder idr. 2006) kot tudi vsakdanjem življenju ter pri delu otrok v organizirani vzgoji in izobraževanju (kot npr. urnik obrokov, počitek, razvoj prijateljstev, dinamike $v$ oddelku). $V$ prid etnografske raziskave $v$ zgodnjem otroštvu govori dejstvo, da poteka v otrokovem okolju (Aubrey idr. 2000), v katerem se otroci počutijo varneje kot v laboratorijskem. Hkrati raziskovalcu omogoča, da raziskuje prakso na mikro in na makro nivoju, saj je dogajanje $v$ raziskovalnem polju - vrtcu - kompleksen preplet ciljev vladajoče politike, sociokulturnih prepričanj o vzgoji otrok znotraj družin in institucij kot tudi prepričanj vzgojiteljev o vzgoji v predšolskem obdobju. Raziskovalcu torej daje številne možnosti raziskovanja različnih vidikov otroštva (Aubrey idr. 2000). Vendarle pa je na tem mestu potrebno izpostaviti, da se etnografske 
raziskave, navkljub mnogim obetajočim prednostim in možnostim, na področju vzgoje in izobraževanje pojavljajo zelo redko (Buchbinder idr. 2006). Med glavne ovire sodita predvsem problematika vstopa v polje pa tudi dejstvo, da je z vidika raziskovalcev etnografsko raziskovanje precej zahtevno in časovno zamudno (npr. eno šolsko leto), poleg tega je potrebna stalna prisotnost raziskovalca (Štemberger 2017).

\section{Študija primera}

Prve študije primera v raziskavah zgodnjega otroštvu so bile v obliki biografij otrok in so služile predvsem terapevtskim namenom (Greig in Taylor 1999). Danes študija primera velja za raziskavo, ki je lahko primerna za raziskovanje zgodnjega otroštva - lahko se osredotoča na posameznega otroka, skupino otrok, oddelek otrok ali na celotni vrtec. Na njeni osnovi pridobimo informacije, ki nam omogočajo poglobljeno razumevanje otrok ali konteksta, ki ga preučujemo. Študije primera lahko vključujejo enega posameznika (eno skupino, eno institucijo ipd.) - v tem primeru gre za t. i. singularne študije primera -, lahko pa je vključenih več posameznikov (skupin, institucij ipd), pri čemer gre za t. i. pluralne študije primera (Mukherji in Albon 2010).

Cilj teh raziskav je lahko opisovanje ali razlaganje. Študije primera so lahko longitudinalne, torej trajajo dlje časa, ali pa prečne, se torej opravijo v nekem trenutku (Coolican 2004). P. Mukherji in D. Albon (2010) opredeljujeta tudi intrinzično, instrumentalno in že prej omenjeno pluralno študijo primera. Za intrinzično velja, da se usmerja v poglobljeno razumevanje posameznega primera - tako se lahko študija primera nanaša na enega otroka, ki ga natančno opazujemo ter se o njem pogovarjamo s starši in pomembnimi drugimi v njegovem življenju; ne gre le za opis otroka in njegovega razvoja, vse je tudi reflektirano in analizirano. $V$ instrumentalni študiji primera je primer instrument oz. orodje, ki raziskovalcu pomaga, da razume nek širši pojav.

Študija primera se ne usmerja v dokazovanje nečesa, pač pa v spoznavanje pojavov, odkrivanje novosti in novih spoznanj, prav zato je primerna za raziskovanje polj, ki še niso dobro poznana, saj na nek način odpira vrata nadaljnjemu raziskovanju.

\section{Akcijska raziskava}

Akcijska raziskava je usmerjena $v$ spreminjanje in izboljševanje vzgojnoizobraževalne prakse, izvajajo jo praktiki, občasno tudi v tesnem sodelovanju z raziskovalci (Robson 2006). Predpostavlja tudi sodelovanje različnih deležnikov. V institucijah, ki izvajajo zgodnje učenje, delujejo in sodelujejo različni strokovnjaki, ki tvorijo neko socialno skupino in za uvajanje spre- 
memb oz. izboljšav, k čemur stremi akcijska raziskava, je podpora te skupine oz. t. i. raziskovalnega tima (raziskovalci, praktiki) zelo pomembna. Vsak član tima ima natančno določene naloge, ki jih mora v okviru akcijske raziskave opraviti, med člani tima se običajno vzpostavi partnerski odnos. Raziskovalci posredujejo praktično-teoretska spoznanja, praktiki pa to povežejo s svojimi izkušnjami. Skupaj tako oblikujejo pomemben proces učenja (Sagadin 1989). Za akcijsko raziskavo je značilen tudi iterativni ciklični proces, ki vključuje opredelitev problema, analizo stanja, identifikacijo različnih rešitev, načrtovanje akcije, identifikacijo možnih ovir, izvajanje akcije in spremljanje, evalvacijo ter refleksijo (Kemmis in McTaggart 2005). Proces ima lahko več ponovitev, saj iz vsakokratne evalvacije in refleksije črpa nove izzive za raziskovanje ter izboljševanje prakse. Akcijsko raziskovanje se tesno povezuje tudi z vzgojiteljevim profesionalnim razvojem, saj vzgojitelj preko raziskovanja lastne prakse krepi svoje kompetence. Glede na to, je da je to raziskovanje »iz prakse za prakso«, ga vzgojitelji tudi lažje sprejmejo, kar dejansko omogoča raziskovalni pristop k uvajanju izboljšav oz. sprememb.

\section{Pristop kritičnega dogodka}

Pristop kritičnega dogodka je dobro poznan način raziskovanja različnih področjih kot npr. na področju psihologije, medicine, nekoliko manj pa na področju vzgoje in izobraževanja (Rous 2015). Flanagan (1954, po Rous 2015) definira pristop kritičnega dogodka kot fleksibilno raziskavo, ki poudarja zbiranje informacij o posebnem dogodku, aktivnosti ali vedenju, ki ga identificiramo kot kritični dogodek in ga lahko uporabimo za naslavljanje praktičnih problemov na nekem področju. Na načelni ravni sodi v okvir kvalitativne paradigme, lahko pa vključuje tudi nekatere značilnosti kvantitativne metodologije. Kritični dogodek je raziskovalni pristop, za katerega se zdi, da je $v$ luči možnosti, ki jih ponuja - premalo uporabljen na področju zgodnjega učenja in poučevanja. B. S. Rous (2015) izpostavlja tri prednosti takega raziskovanja: (i) sodelujočim omogoča, da upoštevajoč cilje raziskovalca sami izberejo dogodek, za katerega menijo, da je pomemben; (ii) uporaben je tudi za raziskovanje pojavov, o katerih le malo vemo in jih slabše razumemo; (iii) omogoča generiranje novih konstruktov, konceptov in teorij. Na ta način se pristop kritičnega dogodka usmerja v identifikacijo (ne)učinkovitih praks, povezanih z vsakdanjimi izzivi vzgojno-izobraževalne prakse, in lahko predstavlja pomembno izhodišče tako za izboljševanje vzgojno-izobraževalne prakse kot tudi nadaljnje raziskovanje odkritih področij oz. pojavov.

$\checkmark$ preglednici 2 povzemamo osnovne možnosti, ki jih na področju raziskovanja zgodnjega učenja in poučevanja omogočajo posamezne raziskave. 
Preglednica 2 Osnovne možnosti raziskovanja zgodnjega učenja in poučevanja glede na vrsto raziskave

\begin{tabular}{ll}
\hline Raziskava & Priložnosti v raziskovanju zgodnjega otroštva \\
\hline Pregledna raziskava & $\begin{array}{l}\text { Na osnovi večjega števila vključenih lahko dobimo širši pogled na } \\
\text { obravnavano tematiko. }\end{array}$ \\
\hline Etnografska raziskava & $\begin{array}{l}\text { Raziskovanje otrokovega razvoja v kontekstu in avtentičnem oko- } \\
\text { lju, kar omogoča spoznavanje otroka z različnih perspektiv. }\end{array}$ \\
\hline Študija primera & $\begin{array}{l}\text { Osredotoča se na en primer in tako omogoča poglobljeno razu- } \\
\text { mevanje primera in konteksta. }\end{array}$ \\
\hline Akcijska raziskava & $\begin{array}{l}\text { Izhaja iz prakse, iz zaznave praktikov, da je potrebno nekaj spre- } \\
\text { meniti; pomembno pripomore pri profesionalnem razvoju vzgoji- } \\
\text { teljev. }\end{array}$ \\
\hline $\begin{array}{l}\text { Pristop kritičnega } \\
\text { dogodka }\end{array}$ & $\begin{array}{l}\text { Identifikacija neučinkovitih vzgojno-izobraževalnih praks (in po- } \\
\text { sledično možnost iskanja rešitev). }\end{array}$ \\
\hline
\end{tabular}

\section{Tehnike zbiranja podatkov}

Podatke lahko zbiramo na različne načine oz. z različnimi tehnikami; izbor tehnike je odvisen od ciljev raziskave pa tudi od potencialnih vključencev $v$ raziskavo. Pri raziskovanju zgodnjega učenja in poučevanja pa moramo biti še posebej pozorni tudi na to, da moramo, $v$ kolikor so $v$ raziskavo vključeni tudi otroci, tehnike zbiranja podatkov prilagoditi njihovim zmožnostim in značilnostim. Uporabljajo se tako tradicionalne tehnike (npr. opazovanje, intervju) kot tudi tehnike, ki se razvijajo $v$ zadnjem obdobju in se usmerjajo $v$ aktivno vlogo otrok $v$ raziskovanju (npr. fotografija, pripovedovanje zgodb ipd.).

\section{Opazovanje}

V vzgojno-izobraževalni praksi je opazovanje dobro uveljavljeno kot orodje, s katerim vzgojitelj opazuje bodisi posameznega otroka bodisi celo skupino in na osnovi tega načrtuje svoje delo. Pri raziskovanju zgodnjega otroštva se opazovanje uporablja kot tehniko neposrednega zbiranja podatkov (Mukherji in Albon 2010). Otroke so prvotno opazovali izolirano, nato pa so opazovanje prenesli v običajno vsakdanje življenje otrok. M. Fawcett (1996) opazovanje otroka $v$ njegovem avtentičnem okolju poimenuje ekološki pristop k opazovanju, ki upošteva tudi vlogo lokacije, prisotnosti drugih ljudi, pričakovanj in pravil v kontekstu, kjer otrok živi. S. Rolfe (2001, v Mukherji in Albon 2010) pa izpostavlja, da je pri zelo malih otrocih in dojenčkih to edini način zbiranja informacij.

Poznamo več oblik opazovanja (Vogrinc 2008), pri čemer na tem mestu 
izpostavljamo le najosnovnejše izmed njih: opazovanje z udeležbo, opazovanje brez udeležbe, strukturirano opazovanje, nestrukturirano opazovanje ipd.

Opazovanje z udeležbo pomeni, da se opazovalec vključi v skupino in v njej prevzame eno izmed vlog, ki jo imajo drug člani skupine (Mesec 1998). Kot izpostavlja Vogrinc (2008), gre za tehniko zbiranja podatkov, pri kateri se socialni procesi preučujejo $v$ naravnih razmerah. Raziskovalec se za dlje časa vključi v skupino, opazuje vedenje članov te skupine, z njimi sodeluje in se skuša vživeti v njih.

Opazovanje brez udeležbe pa, nasprotno, označuje opazovanje, pri katerem opazovalec aktivno ne sodeluje s skupino, njegova vloga je natančno določena in se razlikuje od vlog drugih članov skupine.

Za nestrukturirano opazovanje je značilno, da raziskovalec opazuje na osnovi splošnejših smernic, nima vnaprej določenih kategorij (Vogrinc 2008), zapise pripravi v obliki anekdotskih zapisov (Mesec 1998); pri tem si zapisuje, kar vidi oz. sliši. Glavna prednost te vrste opazovanja je, da se nanjo ni potrebno zelo natančno pripraviti ( $v$ primerjavi s strukturiranim opazovanjem), se pa lahko med opazovanjem zaradi tega pojavi kaka dilema, prav tako se $\mathrm{v}$ primeru pestrega dogajanja lahko kaj izpusti. Ob koncu ima raziskovalec veliko zapisov, ki potrebujejo natančno analizo, rezultate različnih opazovanj pa je težko primerjati (Mukherji in Albon 2010). Na drugi strani pa strukturirano opazovanje temelji na vnaprej določenem načinu in predmetu opazovanja, torej na tem, kaj in kako se bo opazovalo (Vogrinc 2008; Cohen, Manion in Morrison 2007). Pri opazovanju se uporabljajo različni instrumenti oz. protokoli opazovanja, kot so npr. časovni vzorci, sledenje dogodkom, kontrolna lista. Pri časovnih vzorcih raziskovalec opazuje otroka ali skupino otrok v določenih rednih intervalih. Ob tem natančno opredeli, koga in kaj bo opazoval, kaj bo beležil, kako pogosto bo beležil in trajanje vsakega opazovanja. $V$ ta namen si pripravi nek opazovalni formular, tabelo. Sledenje dogodkom sledi podobnim zakonitostim, s tem, da se osredotoča na določene dogodke, v času, ko se ti dejansko dogodijo.

\section{Intervju}

Intervju je ena od najpogosteje uporabljenih tehnik zbiranja podatkov, ki se uporablja tako $v$ kvantitativnem kot $v$ kvalitativnem raziskovanju (Vogrinc 2008). Načeloma gre za pogovor med dvema osebama, pri čemer ena oseba sprašuje, druga pa odgovarja (Sagadin 1995). Raziskovalec preko intervjuja ugotavlja, kaj udeleženci raziskave menijo o neki temi, spoznava njihova čustva, misli, namere itd. Zaradi nekaterih prednosti pred drugimi tehnikami je 
intervju zelo pogosto uporabljena tehnika v raziskovanju vzgoje in izobraževanja, med drugim je zelo primeren tudi za raziskovanje populacije mlajših otrok, ki ne znajo (dobro) brati in pisati (Vogrinc 2008). Poznamo več vrst raziskovalnih intervjujev, in sicer: (i) neposredni intervju, kjer pogovor poteka z osebo, o kateri zbiramo podatke; (ii) posredni intervju, pri katerem podatke o osebi, ki nas zanima, zbiramo s pomočjo drugih ljudi, ki to osebo poznajo; (iii) individualni intervju, kjer spraševalec intervjuva eno samo osebo; (iv) skupinski intervju, pri katerem se spraševalec pogovarja s skupino ljudi (Mužić 1986). Intervjuji so nadalje lahko (v) strukturirani, pri katerih se raziskovalec usmerja v zbiranje podatkov, ki se lahko preoblikujejo v številske podatke, vprašanja pa so natančno določena; (vi) polstrukturirani, za katere so značilna vnaprej pripravljena vprašanja, ki se lahko dopolnjujejo in niso usmerjeni v zbiranje številskih podatkov, ter (vii) nestrukturirani, ki so odprti in zelo podobni vsakdanjemu pogovoru - raziskovalec vodi pogovor na osnovi nekih izhodišč in ne vprašanj (Mukherji in Albon 2010). Avtorja navajata, da je za intervjuje z otroki najprimernejši nestrukturiran intervju ali pa intervju v fokusnih skupinah, zato ti dve obliki podrobneje predstavljamo. Nestrukturirani intervju se prične kot pogovor z vprašanji, ki vzniknejo med pogovorom, pri čemer lahko pobudo prevzame tudi spraševanec. Prav zaradi slednje značilnosti naj bi bil ta intervju primeren za intervjuvanje mlajših otrok, saj slednjim omogoča, da lahko soodločajo o tempu in intervju usmerjajo v različne teme, ki se jim zdijo pomembne. Pri fokusnem intervjuju se raziskovalec pogovarja z več udeleženci hkrati (Vogrinc 2008), običajno je v skupini od 6 do 12 udeležencev. Raziskovalec navadno zavzame vlogo moderatorja, ki spodbudi razpravo in skrbi, da imajo vsi udeleženci možnost sodelovati, da ni dominantnega člana ter da se razprava ne oddalji od cilja. Z vidika uporabe fokusnega intervjuja z malimi otroki P. Lancaster in V. Broadbent (2003) navajata naslednje pozitivne vidike uporabe te tehnike:

- ko se otroci (udeleženci) med seboj poznajo, so fokusne skupine še posebej uspešne;

- spodbujana je interakcija med otroki;

- otroci lahko izpostavijo teme, o katerih bi radi govorili;

- otrokom je pripoznana vloga »strokovnjakov« njihovega področja;

- raziskovalec pridobi vpogled v skupne poglede otrok na vsakdanje življenje;

- skozi interakcijo se porodijo nove ideje;

- tak način »pogovora« je otrokom prijaznejši kot sistem vprašanje - odgovor; 
- otroci so običajno takšnih diskusij že vajeni iz dejavnosti branja oz. jutranjih krogov.

Poudarjata pa, da morajo raziskovalci, če želijo izpeljati fokusni intervju z otroki, znati delati s skupinami otrok, predvsem morajo biti pozorni na morebitne dominantne udeležence.

Pri raziskovanju z otroki se pogosto uporablja tudi narativni ali pripovedni intervju (Cameron 2015), katerega glavna značilnost je, da se skuša čim bolj približati vsakdanji komunikaciji med ljudmi. Spraševalec le usmerja spraševanca in mu pusti, da govori in izraža svoje misli ter ga pri tem ne omejuje (Vogrinc 2008). H. L. Cameron (2015) meni, da je izvajanje takih intervjujev z otroki zelo prijetna in koristna aktivnost. Otroci namreč lahko raziskovalcem omogočijo pomembne vpoglede v svoj vsakdanjik in izkušnje. Avtorica pri tem poudarja, da mora raziskovalec pri intervjuju otrok še toliko bolj upoštevati njihove značilnosti kot pri intervjuvanju odraslih, zlasti starost, udobje in varnost. Pozoren je, da otrok ohranja svoj tempo pogovora, v katerem lahko izrazi svoja stališča, videnje, tudi če se ta vedno ne navezujejo na cilj raziskave.

\section{Kontrolne liste}

Kontrolne liste (tudi »ček liste«) so zelo pogost način zbiranja podatkov za obdobje zgodnjega otroštva. Uporablja se jih lahko za spremljanje (in spodbujanje) otrokovega napredka, hkrati pa se vzgojitelje na ta način spodbuja $\mathrm{k}$ raziskovalnemu pristopu pri načrtovanju dejavnosti (Mukherji in Albon 2010; Dunst, Trivette in Rabb 2015). Kontrolne liste lahko uporabljajo za zbiranje različnih podatkov, kot so npr. podatki o vsakdanjem življenju in delu v predšolskih institucijah, napredku otrok, dejavnostih, uresničevanju ciljev, interesu otrok, sodelovanju s starši.

\section{Vprašalniki}

Vprašalnik razumemo kot instrument zbiranja podatkov, ki lahko vključuje različne tehnike zbiranja podatkov, kot npr. lestvice stališč, ocenjevalne lestvice, anketna vprašanja ipd. (Cencič 2009). V splošnem se pri raziskovanju vzgoje in izobraževanja zelo veliko uporabljajo različni vprašalniki, kar je, ko gre za anketiranje strokovnih delavcev sprejemljivo, kakor hitro pa začnemo razmišljati o raziskovanju z otroki, se glede vprašalnikov porajajo mnoge dileme oz. omejitve. E. De Leeuw meni (2011, v Bratož 2018), da otroci pred sedmim letom kognitivno še niso sposobni sistematično izpolnjevati vprašalnikov. Pri sedmih letih pa se pri otrocih zgodijo pomembni premiki v kognitivnem in socialnem razvoju, zato jih raziskovalci lahko že neposredno anke- 
tirajo, pri tem pa vprašalnike ustrezno prilagodijo (npr. grafični, slikovni odgovori ipd.). Raziskovalci z vprašalniki pri otrocih zbirajo predvsem tiste podatke, za katere so najzanesljivejši respondenti, tj. njihova stališča, občutja ipd. Poleg navedenih tradicionalnih tehnik zbiranja podatkov se $v$ raziskovanju z otroki v zadnjih desetletjih oblikujejo tudi druge, na otroka osredotočene tehnike zbiranja podatkov, ki se usmerjajo $v$ aktivno vključevanje otrok $\checkmark$ raziskovanje.

V tem kontekstu se pojavlja koncept »ustvarjalnega poslušanja otrok«, ki se povezuje s konceptom stotih jezikov otrok - razumevanjem, da otroci »govorijo«/se izražajo o svojih izkušnjah, dojemanjih, skrbeh preko glasbe, govora, oblikovanja, risanja in podobnih nebesednih sredstev (Robertson-Holmes 2005). Razumevanje in upoštevanje otrokovega "glasu « v raziskovanju izpostavlja Malewski (2005), ki spomni, da je pri raziskovanju z otroki potrebna previdnost oz. da je potrebno razviti metodologijo, ki bo otroke opolnomočila za sodelovanje $v$ raziskavi ter na ta način ponudila ustrezno alternativo že uveljavljenim metodološkim postopkom, ki običajno niso prilagojeni vključevanju otrok. Gre torej za razmišljanje, da je potrebno razviti raziskovalne tehnike, ki bodo omogočile izražanje otrok na njim prilagojen način in ne »le« preko verbalnega odgovora na vprašanje. Slednje nikakor ne pomeni, da je potrebno opuščanje tradicionalnih tehnik, saj, kot opozarjata P. Mukherji in D. Albon (2010), tudi pri raziskovanju otrok ne gre zanemariti vloge intervjujev in pomembne vloge opazovanja, zlasti pri raziskovanju, ki vključuje zelo majhne otroke oz. dojenčke.

Pomembno je, da raziskovalci ne podcenjujejo ali precenjujejo otrok, pač pa razvijajo pristope oz. tehnike, ki lahko sledijo otrokovim interesom ter ravni znanja in razumevanja. Tako Malewski (2005) navaja primer dveletnika, od katerega ne moremo pričakovati odgovorov na vprašanja na ravni odraslega človeka, od malčka tudi ne moremo pričakovati, da bo v času intervjuja dlje časa mirno sedel na mestu. Ob tem spet izpostavljamo etični vidik, torej da otroka pri raziskovanju ne smemo spraviti v položaj, ki mu povzroča tesnobo. Poleg tega je potrebno izbrati tehnike, ki ustrezajo otrokom v specifični raziskavi. $V$ nadaljevanju predstavljamo nekaj tehnik zbiranja podatkov, ki jih lahko - poleg tradicionalnih, vendar prilagojenih otrokom - tudi uporabimo pri raziskovanju zgodnjega otroštva.

\section{Fotografija}

Fotografija se pogosto uporablja pri raziskovanju otrok. T. Cook in E. Hess (2007) izpostavljata nekaj pomembnih prednosti rabe fotografije pri raziskovanju otrok, glavna od njih je aktivna vključenost otrok: 
- uporaba fotoaparata je aktivnost, ki otroke zelo pritegne;

- otroci lahko z (moderno) opremo ustvarijo zelo dobre fotografije;

- otroci so običajno zelo vešči uporabe fotoaparatov in imajo na ta način nadzor nad svojim početjem, zato obstaja velika verjetnost, da bodo fotografije odsevale otrokove dejavnosti, interese, skrbi ipd.

- raziskovanje preko fotografij predstavlja za otroka mnogo oprijemljivejšo izkušnjo, pogosto se preko fotografije tudi lažje izrazi (Clark 2011);

- uporaba digitalnih fotoaparatov omogoča, da je fotografija vidna (in tudi natisnjena) takoj, kar povečuje otrokovo motivacijo (Clark 2011).

Fotografija hkrati raziskovalcu tudi omogoča, da jo uporabi kot vizualno oporo otroku tudi kasneje v raziskovalnem procesu (Clark 2011) oz. jo uporabi kot motivacijsko sredstvo ob pričetku intervjuja oz. diskusije (Winter 2015). Potrebno pa je upoštevati tudi etični vidik, in sicer soglasje vključenih za fotografiranje ter lastništvo fotografij. Smiselno je, da raziskovalec poskrbi, da tudi otrok dobi fotografije, ki jih je posnel.

$S$ hitrim razvojem tehnologije, predvsem $z$ uporabo pametnih telefonov, je fotografiranje postalo zelo preprosto, bistveno pa se je povečala tudi možnost za izdelovanje videoposnetkov, ki jih tudi lahko uporabimo $v$ raziskovalne namene. Podobno kot pri fotografiji (Prosser in Burke 2007) lahko otrokom damo nalogo, da posnamejo nek dogodek, osebo ali situacijo in tako pridobimo njihovo perspektivo glede tega.

\section{Risbe}

A. Veale (2005, v Mukherji in Albon 2010) meni, da se otroške risbe že vrsto let uporabljajo kot orodje za ocenjevanje kognitivnega in emocionalnega funkcioniranja otrok. Pri tem pa nekateri (npr. Cox 1998) opozarjajo, da je to ocenjevanje podrejeno pričakovanjem zahodnih kultur in da ocenjevanje realističnih momentov postavlja na stranski tir simbolizem risbe, predvsem pomen, ki ga risbi pripisuje njen avtor. Risbe pa so vendarle lahko pomembno raziskovalno orodje za obdobje zgodnjega otroštva. Za otroke risba predstavlja pomembno sredstvo komuniciranja pomenov tem, ki imajo za njih pomen, razumevanja tem, njihove perspektive (Einarsdottir, Dockett in Perry 2009). Je pa pri risbah potrebna velika previdnost glede interpretacije, zato je ključno, da se raziskovalci z otroki o njihovih risbah pogovorijo, brez pogovora gre namreč le za golo (subjektivno) raziskovalčevo razlago narisanega. $\checkmark$ pogovoru z otrokom lahko raziskovalec namreč ugotovi, kako je potekal proces risanja, kaj je bil otrokov namen vključevanja elementov v risbo, in na ta način razume ter interpretira proces risanja. Risanje pomeni konstruktiven 
proces razmišljanja $v$ akciji in ne toliko razvijanje sposobnosti vizualne prezentacije svetu (Cox 2005). Pri risbah je potrebno upoštevati tudi kontekst, v katerem so nastale. Kot ugotavlja K. Winter (2015), raziskovalci k risanju pristopajo na dva načina: načrtovano (otroci rišejo glede na navodila raziskovalca) in spontano (otroci rišejo brez navodil raziskovalca). Med načrtovanimi nalogami so tako risanje sebe, nekoga drugega, vključenega v nek dogodek, dogodka samega, nekega mesta (npr. moj najljubši park), čustva ... Raziskovalci nato spodbudijo $k$ pripovedovanju o narisanem in na ta način dobijo vpogled $v$ otrokovo perspektivo in izkušnje.

Poleg tega, splošnejšega, pristopa $\mathrm{k}$ uporabi risbe se $\mathrm{v}$ raziskovanju uporabljajo tudi specifičnejši načini risanja, kot je, denimo, kartiranje (risanje zemljevida socialnega in fizičnega okolja). A. Clark (2011) je uporabila kartiranje s skupinami mlajših otrok, ki so skupaj (tudi s sodelovanjem raziskovalca) ustvarili zemljevid igralnice, pri čemer je bila začetna točka te naloge fotografiranje igralnice. Uporabljajo se lahko tudi različni diagrami (časovne premice, Vennov diagram, dnevna rutina, ipd.), ki jih otroci ustvarijo skupaj z raziskovalci (Winter 2015). K. Anderson in S. Baladin (2011) omenjata tudi t. i. zgodbe v obliki ilustracij (angl. storybooks), ko, denimo, otroci v knjižici predstavijo neke situacije, dogodke ipd.

\section{Pripovedovanje zgodb}

V raziskovanju otrok je pripovedovanje zgodb (angl. storytelling) dokaj uveljavljena tehnika zbiranja podatkov (Marjanovič Umek, Fekonja in Kranjc 2004). Na področju zgodnjega učenja in poučevanja se pripovedovanje zgodb pogosto povezuje z lutkami, ki spodbudijo otroka, da govori o svojih čustvih, lahko pa otroci pripovedujejo tudi svoje zgodbe. V okviru uporabe lutk se velikokrat omenja koncept t. i. Persona Dolls (osebnostne lutke) - gre za lutke, ki imajo vsaka svojo zgodbo. Na ta način se otroka spodbudi, da preko lutk spregovori o svojih čustvih (Mukhjeri in Albon 2010). Lahko pa se uporablja tudi druge lutke; pomembno je, da ima otrok na razpolago različne lutke in jih lahko po lastni izbiri vključi v svoje pripovedovanje. Izbrane lutke predstavi raziskovalcu in pripoveduje zgodbo. Pripovedovanje se lahko spodbudi tudi z vizualnimi izhodišči (slika, posnetek) (Cameron 2015).

\section{Igra dopolnjevanja zgodb}

Igra dopolnjevanja zgodb zapolnjuje vrzel v raziskovanju socio-emocionalnega razvoja otrok. Pri raziskovanju tega segmenta se raziskovalci največkrat opirajo na poročila in opazovanja odraslih ter veliko manj na poglede in izkušnje otrok (Yuval-Adler in Oppenheim 2015). Pri igri dopolnjevanja zgodb 
otroci nadaljujejo zgodbo, ki jo na različne načine prične odrasli, $z$ uporabo nekih izhodišč (zelo pogosta je prav lutka). Preko izhodišča se otroka sooči s čustveno evokativnim pričetkom zgodbe, ki jo nato otrok nadaljuje, razvije in ponudi rešitev. Preko pripovedovanja in iskanja rešitev tako raziskovalec odkrije odnose, čustva otrok. Hkrati pa zaključevanje zgodbe od otroka zahteva, da čustva organizira $v$ koherentno zgodbo, da jih regulira in gradi na prezentaciji notranjega sveta, svojih edinstvenih izkušenj pa tudi kulturnega ter etničnega ozadja. Raziskovalec mora znati zelo dobro usmerjati otroke oz. jim pomagati pri razvijanju pripovedovanja in se čim bolj oddaljiti od sistema vprašanj in odgovorov. A. Greig in Y. Taylor (1999) dopolnjevanje zgodb omenjata predvsem kot način ocenjevanja kakovosti navezanosti predšolskega otroka na starše.

Fotografija, risba, pripovedovanje zgodb ter igra dopolnjevanja zgodb sodijo med t.i. ustvarjalne tehnike, torej takšne, pri katerih od otrok pričakujemo, da ustvarijo fotografijo, risbo ali zgodbo. Na ta način otrokom omogočajo na eni strani sodelovanje na način, ki se bolj prilega njihovemu svetu (v primerjavi z običajnim procesom intervjuja) ter njihovemu načinu izražanja (koncept stotih jezikov), obenem pa jim omogoča, da so $v$ raziskovanje tudi aktivno vključeni, torej niso »le« predmet raziskave, pač pa slednjo tudi soustvarjajo.

\section{Zaključek}

V prispevku smo se usmerili v nekaj vidikov raziskovanja področja zgodnjega učenja in poučevanja, pri čemer smo se dotaknili vprašanja etičnosti pri raziskovanju tega občutljivega obdobja, predstavili smo možnosti različnih pristopov $\mathrm{k}$ raziskovanju, različnih vrst raziskav ter različnih, tako tradicionalnih kot nekaterih novejših, tehnik zbiranja podatkov. Na osnovi zapisanega ugotavljamo predvsem dvoje:

- Pri raziskovanju zgodnjega učenja in poučevanja je potrebno zaradi ranljivosti otrok in zaradi skrbi za njihovo dobrobit dosledno upoštevati etična načela pri raziskovanju; paziti je potrebno, da raziskava ne bi na kakršenkoli način škodila otroku. Starše otrok, ki jih povabimo v raziskavo, je potrebno natančno in jasno seznaniti s cilji in z načinom vključevanja otrok ter njihovo vlogo v raziskavi. Pri tem naj starši, če je le mogoče (glede na starost), upoštevajo voljo otrok, raziskovalec pa naj bo ves čas pozoren na morebitne znake, ki nakazujejo, da otrok ne želi (več) sodelovati v raziskavi.

- V raziskovanju zgodnjega učenja in poučevanja poznamo različne pri- 
stope, vrste raziskav ter tehnike zbiranja podatkov. Smiselno je, da se raziskovalec o izboru odloča na podlagi vsakokratnih ciljev raziskave in pri tem upošteva tudi zmožnosti ter sposobnosti udeležencev in razmisli, na kakšen način lahko le-ti sodelujejo $v$ raziskavi. Možno je tudi kombinirati: tako lahko, denimo, v raziskavi uporabimo elemente kvantitativnega in kvalitativnega raziskovanja ali študijo primera, ki vsebuje elemente akcijskega raziskovanja. Podobno velja tudi za tehnike zbiranja podatkov - možne, celo zaželene so različne kombinacije tehnik oz. t. i. multimodalnost, ki daje možnost celostnega pogleda in multiple perspektive.

\section{Literatura}

Anderson, K., in S. Balandin. 2011. "The Storybook Method: Research Feedback with Young Participants."Augmentative and Alternative Communication 27 (4): 279-291.

Aubrey, C., T. David, R. Goodfrey in L. Thompson. 2000. Early Childhood Research: Issues in Methodology and Ethics. London: Routledge.

Bratož, S. 2018. »Anketiranje tretješolcev s spletnim vprašalnikom. V Oblikovanje inovativnih učnih okolij, ur. T. Štemberger, S. Čotar Konrad, S. Rutar in A. Žakelj, 237-251. Koper: Založba Univerze na Primorskem.

Buchbinder, M., J. Longhofer, T. Barrett, P. Lawson in J. Floersch. 2006. »Ethnographic Approaches to Child Care Research: A Review of the Literature.« Journal of Early Childhood Research 4 (1): 45-63.

Cameron, H. L. 2015. »Ethical, Narrative, and Projective Processes in Research Interviews with Young Children. "V Handbook of Research Methods in Early Childhood:Research Methodologies, ur. O. N. Sarcho, 277-323. Charlotte, NC: Information Age Publishing.

Cencič, M. 2009. Kako poteka empirično pedagoško raziskovanje. Ljubljana: Zavod Republike Slovenije za šolstvo.

Clark, A. 2011. »Multimodal Map Making with Young Children: Exploring Ethnographic and Participatory Methods." Qualitative Research 11 (3): 311-330.

Cohen, L., L. Manion in K. Morrison. 2007. Research Methods in Education. London: Routledge.

Cook, T, in E. Hess. 2007. »What the Camera Sees and from Whose Perspectivein Enlightening Adults ." Childhood 14 (1): 29-45.

Coolican, H. 2004. Research Methods and Statistics in Psychology. London: Hodder Arnold.

Cox, M. 1998. »Drawings of People by Australian Aboriginal Children: The Intermixing of Cultural Styles." Journal of Art and Design Education 17 (1): 71-79.

Cox, S. 2005. »Intention and Meaning in Young Children's Drawing.«International Journal of Art and Design Education 24 (2): 115-125. 
Creswell, W. J. 2008. Educational Research: Planning, Conducting, and Evaluating Quantitative and Qualitative Research. Upper Saddle River, NJ: Pearson Education.

- 2014. Research Design: Qualitative, Quantitative and Mixed Methods Approach. Thousand Oaks, CA: Sage.

De Leeuw, E. 2011. »Improving Data Quality When Surveying Children and Adolescents: Cognitive and Social Development and Its Role in Questionnaire Construction and Pretesting." Predstavljeno na Annual Meeting of the Academy of Finland, Naatali, 10.-12. maj.

Dunst, C. J., C. M. Trivette in M. Rabb. 2015. »Utility of Implementation and Intervention Performance Checklists for Conducting Research in Early Childhood Eudcation. "V Handbook of Research Methods in Early Childhood: Research Methodologies, ur. O. N. Sarcho, 247-277. Charlotte, NC: Information Age Publishing.

Dunn, J. 2005. »Naturalistic Observations of Children and Their Families. « V Researching Children Experience: Approaches and Methods, ur. S. Greene in D. Hogan, 87-101, London: Sage.

Einarsdottir, J., S. Dockett in B. Perr. 2009. »Making Meaning: Children's Perspectives Expressed through Drawings."Early Childhood Development and Care 179 (2): 217-232.

Fawcett, M. 1996. Learning Through Child Observation. London: Jessica Kingsley.

Flanagan, J. C. 1954. »The Critical Incident Technique.« Psychological Bulletin 51 (4): 327-358.

Greig, A., in J. Taylor. 1999. Doing Research with Children. London: Sage.

James, A. 2007. „Giving Voice to Children's Voices: Practices and Problems, Pitfalls and Potentials." American Anthropologist 109 (2): 261-272.

Kemmis, S., in R. McTaggart. 2005. »Participatory Action Research: Communicative Action and Public Sphere.«V The Sage Handook of Qualitative Research, ur. N. k. Denzin in Y. S. Lincoln, 559-603: London: Sage.

Kodelja, Z. 2017. »Etičnost edukacijskega raziskovanja.«Šolsko polje 27 (1-2): 73 87.

»Konvencija o otrokovih pravicah.« 1989. Uradni list Socialistične Federativne Republike Jugoslavije, št. 15.

Lancaster, P., in V. Broadbent. 2003. Listening to Young People. Maidenhead: Open University Press.

Langston, A., L. Abbott, V. Lewis in M. Kellett. 2004. »Early Childhood."V Doing Research with Children and Young People, ur. S. Fraser, V. Lewos, S. Ding, M. Kellett in C. Robinson, 147-160. London: Sage.

Lincoln, S. Y., in G. E. Guba. 2000. »Paradigmatic Controversies, Contradictions, and Emerging Confluences.« V Handbook of Qualitative Research, ur. K. N. Denzin in Y. Norman, 163-189. Thousand Oaks, CA: Sage.

Malewski, E. 2005. »Epilogue: When Children and Youth Talk Back.«V Power and 
Voice in Research with Children, ur. D. S. Soto in B. B Swadener, 215-222. New York: Peter Lang.

Marentič Požarnik, B. 1990. »Za pluralizem modelov spoznavanja, raziskovanja in delovanja v pedagoških znanostih.«Sodobna pedagogika 39 (1-2): 1-14.

Marjanovič Umek, L., U. Fekonja in S. Krajnc. 2004. »Pripovedovanje zgodbe kot pristop za ugotavljanje otrokovega govornega razvoja.«Psihološka obzorja 13 (1): 43-64.

Mažgon, J. 2006. »Od monometod h kombiniranim raziskovalnim pristopom.« Sodobna pedagogika 57 (5): 98-108.

_. 2008. Razvoj akcijskega raziskovanja na temeljnih predpostavkah kvalitativne metodologije. Ljubljana: Filozofska fakulteta.

Mesec, B. 1998. Uvod v kvalitativno raziskovanje $v$ socialnem delu. Ljubljana: Visoka šola za socialno delo.

Mukherji, P., in D. Albon. 2010. Research Methods in Early Childhood. Los Angeles: Sage.

Mužić, V. 1994. »Sinteza paradigem pedagoškega raziskovanja - zakaj? kako?« Sodobna pedagogika 43 (3-4): 162-173.

Prosser, J., in C. Burke. 2007. »Childlike Perspectives through Image-Based Educational Research."V Handbook of the Arts in Qualitative Research: Perspectives, Methodologies, Examples and Issues, ur. J. G. Knowles in A. Cole, 407421. Oxford: Oxford University Press.

Rayna, S., in F. Laevers. 2011. »Understanding Children from o to 3 Years of Age and its Implications for Education: What's New on the Babies' Side Origins and Evolutions." European Early Childhood Education Research Journal 19 (2): 161-172.

Robertson-Holmes, G. 2005. Doing Your Early Research Project: A Step-by-Step Guide. London: Sage.

Robson, C. 2006. Developing Thinking and Understanding in Young Children: An Introduction for Students. London: Taylor and Francis.

Rolfe, S. 2001. »Direct Observation.«V Doing Early Childhood Research: International Perspectives on Theory and Practice, ur. G. MacNaughton, S. Rolfe in I. Siraj-Blatchford, 309-325. Buckingham: Open University Press.

Rous, B. S. 2015. »Using the Critical Incident Technique in Early Childhood Research."V Handbook of Research Methods in Early Childhood: Research Methodologies, ur. O. N. Sarcho, 225-247. Charlotte, NC: Information Age Publishing.

Sagadin, J. 1989. »Akcijsko in tradicionalno empirično pedagoško raziskovanje.«Sodobna pedagogika 39 (5-6): 242-256.

—_. 1995. »Nestandadizirani intervju. Sodobna pedagogika 46 (7-8): 311322.

Rutar, S. 2014. »Ali imajo otroci resnično priložnost za samoizražanje v vzgoji in izobraževanju?« V Communication, ur. P.-M. Rabensteiner in G. Rabenstei- 
ner, 170-186. Internationalization in Teacher Education 4. Baltmannsweiler: Schneider Verlag Hohengehren.

Štemberger, T. 2017. »Etnografska raziskava na pedagoškem področju.« Revija za elementarno izobraževanje 10 (1): 73-83.

Veale, A. 2005. „Creative Methodologies in Participatory Research with Children."V Researching Children's Experiences: Approaches and Methods, ur. S. Greeene in D. Hogah, 253-273. London: Sage.

Vogrinc, J. 2008. Kvalitativno raziskovanje na pedagoškem področju. Ljubljana: Pedagoška fakulteta.

Winter, K. 2015. »Innovative Qualitative Research Methods With Children Aged 4-7 Years."V Handbook of Research Methods in Early Childhood: Research Methodologies, ur. O. N. Sarcho, 479-523. Charlotte, NC: Information Age Publishing.

Yuval-Adler, S., in D. Oppenheim. 2015. "Story Completion Play Narrative Methods for Preschool Children."V Handbook of Research Methods in Early Childhood: Research Methodologies, ur. O. N. Sarcho, 323-383. Charlotte, NC: Information Age Publishing.

\section{Some Aspects of Research in Early Childhood Education}

The field of educational research is very wide and diverse. In this context, some subfields in the educational research have been developed, focusing on particular areas within education. One of this specific fields is the research of phenomena in early childhood, which has, under the influence of Anglo-Saxon tradition made a shift from the traditional positivist approach towards more constructivist approach In the paper we emphasise the particularities of the research in early childhood research, and address ethics in research, approaches in research and the data collection methods when doing the research within the early childhood education

Keywords: educational research, early childhood, ethics, research methods 